Management Research, The

Academy of Management

\title{
Internationalization of Firms: Revitalizing the Board of Directors After a Cross-Border Acquisition
}

\begin{tabular}{|r|l|}
\hline Journal: & $\begin{array}{l}\text { Management Research, The Journal of the Iberoamerican Academy of } \\
\text { Management }\end{array}$ \\
\hline Manuscript ID & MRJIAM-10-2015-0614.R2 \\
\hline Manuscript Type: & Research Paper \\
\hline Keywords: & $\begin{array}{l}\text { Board of directors, Acquisitions, integration manager, Corporate } \\
\text { governance }\end{array}$ \\
\hline \multicolumn{2}{|l}{} \\
\hline
\end{tabular}




\begin{abstract}
Purpose - This paper aims to illustrate the importance of introducing the integration manager (i.e., an executive position used to channel the acquiring firm's course of action and strengthen the success of a post-acquisition integration process) within the acquiring firm's board of directors.
\end{abstract}

Design/methodology/approach - This is a theoretical paper that introduces the integration manager within the board of privately held firms going internationally via acquisitions and serving as an "out-insider" director able to balance the conflicting demands of the previously separated entities during their integration process. The authors present an explanatory case study that empirically contributes to board of directors' design for internationalization.

Findings - We posit that the integration manager serves as an "out-insider" director of the board for privately held firms, possessed by large-block shareholders, going internationally via acquisitions, providing the necessary expertise and knowledge of the target firm's products and industry.

Originality/value - The provided study aims to demonstrate that international acquisitions, even though apparently less risky than greenfield investments, may require additional neutral information flow - both within the due diligence process and the post-acquisition integration - that only outsiders possess. Such outsider has been individuated in the integration manager whose crucial role focuses on smoothing the pre- and post-acquisition integration processes.

Keywords Board of directors, acquisitions, integration manager, corporate governance.

Paper type Research paper

\title{
Resumen
}

Propósito - Estes artículo pretende ilustrar la importancia de introducir el gerente de integración (es decir, una posición ejecutiva utilizada para canalizar el curso de acción de la empresa y fortalecer el éxito de un proceso de integración post-adquisición) dentro de la junta directiva de la empresa compradora.

Diseño / metodología / aproximación - Este es un artículo teórico que introduce el gerente de integración dentro de la junta directiva de las empresas privadas que van a nivel internacional a través de adquisiciones y sirviendo como director de "fuera-adentro" capaz de equilibrar las demandas conflictivas de entidades, previamente separadas, durante su proceso de integración. Los autores presentan un caso de estudio explicativo que empíricamente contribuye a el diseño de la junta directiva para la internacionalización. 
Resultados - Nos postulan que el gerente de integración sirve como director de "fueraadentro" de la Junta para las empresas privadas, poseído por los accionistas de grandes bloques, pasando a nivel internacional a través de adquisiciones, aportando la ncesaria experiencia y conocimientos de los productos y la industria de la empresa objetivo.

Originalidad / valor - El estudio provisto demostró que, yendo a nivel internacional a través de adquisiciones, aunque aparentemente menos arriesgado que las inversiones en nuevas instalaciones, puede requerir el flujo de información neutral adicional - tanto dentro del proceso de due diligence y la integración post-adquisición - que sólo los ajenos poseen. Tales ajenos se han individualizado en el gestor de integración cuyo papel en suavizar los procesos de integración antes y después de la adquisición fue descrito.

Palabras clave: junta directiva, adquisiciones, gerente de integración, gobierno corporativo.

Tipo de artigo: Artigo de investigação

\section{Resumo}

Propósito/Objectivo

Metodologia

Resultados

Originalidade/valor

Palavras-chave

Tipo de artigo Artigo de investigação 
Introduction

Managing firm growth via internationalization, with a special emphasis on cross-border acquisitions, has been a mainstream of management studies in the last decades (Werner, 2002; Hitt and Pisano, 2003; Aharoni et al., 2011; Reddy, 2014; Hitt et al., 2016). In addition, an attractive subfield at the interface of international business literature and corporate governance relates to the conditions leading international strategy (Tihanyi et al., 2003; Hitt et al., 2006; Oesterle et al., 2013; Dagnino et al., 2014). On the other hand, the choice to internationalize may lead to situations wherein, inevitably, most decisions and actions have to be delegated with the risk of incurring in severe agency conflicts between principals and agents (Nohria and Ghoshal, 1994; Roth and O'Donnell, 1996). This is more evident when firms go internationally via acquisitions, relatively to other entry modes, such as joint ventures (Iborra, 2004) - a strategic choice that could dramatically affect both the acquiring and acquired firm, particularly with regard to the crucial post-acquisition integration process (Ibora and Dolz, 2006; Canabal and White III, 2008).

The risk of potential conflicts between principals and agents calls for a wider application of some traditional effective Corporate Governance Mechanisms (CGMs) serving as tools to align shareholders' and managers' interests. For instance, many studies suggest that board members would be better able to exert their advising role if they would possess the right knowledge and expertise of the business and its related industry (Carpenter and Westphal, 2001; Pfeffer and Salancik, 2003; Hillman and Dalziel, 2003).

Drawing on corporate governance theory, this paper proposes the insertion of the integration manager within the acquirer's board of directors as the best qualified individual able to contribute to such crucial CGM through her/his expertise and knowledge of the target firm's industry and products. Previous literature on international business contends that integration managers play multiple roles during acquisitions (Dagnino and Pisano, 2008; 
Teerikangas et al., 2011). More specifically, on the one hand, the integration manager helps the top management team to better formulate and implement corporate strategy, particularly in the context of cross-border acquisitions (Shimizu et al., 2004); while, on the other hand, s/he might facilitate the acquisition process making it smoother and more effective. Yet, we give recognition to a novel and additional role: indeed, we look forward to introducing such individual within the board of privately held firms going internationally via acquisitions and serving as an "out-insider" director able to balance the conflicting demands of the previously separated entities during their integration process.

After having provided a conceptual response to our research question (namely, whether the role of the "integration manager", as an additional CGM enhancing the effectiveness of the board of directors, can positively affect the performance of a cross-border acquisition), we though acknowledge that an empirical challenge remains in evaluating the effectiveness of the integration manager's inclusion within the acquiring firm's board of directors for strategic and control issues. With a specific focus on this issue, our study is inspired by the qualitative analysis of an acquisition of a Spanish firm by an Italian privately held firm operating in the telecommunication industry. We provide a case study of both explanatory and instrumental nature (Stake, 1995) to empirically illustrate our conceptual arguments and juxtapose the extent to which they are likely to hold true in real life practice.

This paper is organized as follows. Section 2 summarizes the literature on the role of board of directors in the context of international acquisitions describing the integration manager and her/his main traits. From a corporate governance perspective, section 3 speculates on the role of the integration manager who may serve as an additional strategic tool providing better information, monitoring and control, especially if taking a seat on the board of the acquirer - yet a largely unexplored topic and main focus of our analysis. Section 4 offers a discussion on the methodological landscapes of our empirical study; specifically, 
we focus on the criteria for theoretical sampling, then we offer a concise case description illustrating data collection and analysis procedures. Section 5 focuses on a case study resembling the preliminary assumptions of our paper. The final section summarizes our conclusions and managerial implications.

\section{Theoretical Background}

\section{The Board of Directors}

Scholars typically describe board of directors as the formal institution linking a firm's shareholders with the managers entrusted of the daily functioning of a firm (Fama and Jensen, 1983; Monks and Minow, 1995). Even though they vary considerably depending on the country in which the firm operates (Charkham, 1994), they are CGMs empowered by shareholders to exercise ultimate control over top management. Nowadays, the role of boards has changed a lot from what it used to be in the past. While they previously used to be almost passive and formal institutions simply able to ratify management decisions, their current importance/activities have grown exponentially (Golden and Zajac, 2001), particularly when considering the monitoring action to which they have been exposed by media and investors (Forbes and Milliken, 1999). Moreover, the expansion of accounting and financial scandals (such as Enron, Parmalat, and Worldcom) have been pushing for the board's greater involvement in strategic decisions, such as corporate-level strategies, acquisitions and alliances. In such standpoint, it is crucial to understand what characteristics boards do need to exhibit in order to be able to provide a correct evaluation of a cross-border acquisition; or, in different words, what peculiarities their directors need to possess in order to have the right knowledge and expertise to allow such CGM's correct functioning.

The primary role of directors is protecting shareholders' interest and monitoring management behavior; to perform this task, they are empowered to discipline or remove 
ineffective management teams (Williamson, 1984). Therefore, they can be considered as agents of the owners/shareholders whose fundamental activity is overseeing management choices. Furthermore, they are supposed to be over-skilled in industry matters and, hence, able to provide managers of both advice and counsel. Thus, the main difference between board and management is that the former is primarily responsible to monitor and shape strategy, while not always for elaborating and implementing strategic choices as the latter (Fama and Jensen, 1983).

Empirical literature shows the importance of boards of directors in situations of severe agency costs - for instance, when negotiating and implementing an acquisition - but with little evidence in connecting board features to corporate performance (Barnhart et al., 1994). Instead, board characteristics have been studied to evaluate how they influence acquisition performance via the CEO tenure (Walters et al., 2007). However, some authors posit that boards and top management teams represent a legitimation signal able to convince external investors of the goodness and potential value of a certain investment, such as an acquisition (Certo, 2003; Cohen and Dean, 2005; Higgins and Gulati, 2006).

In conclusion, we emphasize the analysis performed by Redor (2015). By considering "four board attributes: (1) board independence, (2) board size and director-specific attributes, (3) board ownership and compensation, and (4) multiple directorships" (Redor, 2015:1), the author concludes that "the impact of board attributes on shareholder wealth in mergers and acquisitions is specific to each firm" (Redor, 2015:1).

\section{The Role of the Board of Directors in the Context of an International Acquisition}

International acquisitions are phenomena through which a firm (the acquirer) decides to buy the controlling stock of another firm operating in a foreign country (the target) for strategic or financial motives (Hitt et al., 2015). Since "great difficulties in achieving the expected value 
resulting from synergies emerge" (Aureli, 2015: 895), they are financially severe operations and, as such, subordinated to the board's approval.

The performance of an acquisition is the measure of its post-transaction effectiveness (Schoenberg, 2006). However, such measures are various. Actually, "most scholars refer to «integration» as an umbrella term for different and distinctive acculturation strategies, e.g. integration, assimilation, separation and marginalization; (...) some studies mix different levels of analysis with respect to culture constructs, e.g. national vs. organizational culture; and finally, there exist various definitions of «M\&A success», which become manifest in a plethora of measurement techniques" (Dauber, 2012: 375). Generally speaking, an international acquisition may be considered effective when it fulfills the primary objectives declared by the management to achieve the board's approval. Such objectives can be of financial diversification via internationalization or strategic goals in foreign markets (Hitt et al., 2015). Managerial literature shows that more than $50 \%$ of cross-border acquisitions do not maintain their promises getting divested very often (Shimizu et al., 2004). Sometimes failure occurs as deals are pushed by hubris (Seth et al., 2000; Picone et al., 2014), some others for cultural incompatibility between the two firms (Datta and Puia, 1995; Björkman et al., 2007; Stahl and Voigt, 2008). Hence, such list of potential problems emphasizes the need to legitimize the acquiring firm's board of a more active role in order to be entitled to provide a better judgment of the deals to be implemented.

Board of directors' effectiveness is typically function of its independence, size and leadership structure (Bange and Mazzeo, 2004). To be independent, it needs to be mostly deprived of any kind of ties to the firm's management and CEO. Therefore, we mainly look at outside directors whose external position implies the highest level of independence. A board that is composed of a good average of outsiders is supposed to take decisions maximizing shareholders' interests (Cotter et al., 1997). Thus, it should be able to evaluate 
the individuated synergies, the target's bidding price and premium, the strategic and organizational fit of the two firms, and any potential issue regarding the overall integration process, especially when the business combination involves firms operating in two different countries.

Of course, considering the complexity of such evaluations and the multifaceted specialization wherein directors should be so competent (members' diversity), it is predictable that, when the size of the board increases, its evaluating and monitoring capacity should also proportionally increase (Barthala and Rao, 1995). Since cross-border acquisitions are risky deals, the size of the board can play an important role. Nevertheless, the presence of many outside directors is not necessarily a positive aspect of board composition. In fact, the benefits corresponding to an increase in size could be outweighed by a cost increment due to a harder communication and a slower decision-making process ${ }^{1}$. Consequently, a limited number of directors, even though reducing competences' width, should speed up the decision-making process rendering it more efficient and effective (Yermack, 1996). Overall, diversity and size can be considered double-edge swords.

In terms the boards' leadership structure, the main issue refers to the individual who is supposed to seat as chairman. Herein, the literature is ambiguous (Baliga et al., 1996; Coles and Hesterly, 2000), but mainly supportive of the idea that, in order to be independent and able to both monitor and judge management actions without any external influence, boards of directors should be led by a person who is different from the CEO (Rechner and Dalton, 1991; Mallette and Fowler, 1992; Daily and Dalton, 1994). Thus, the CEO and the chairman of the board must not coincide onto the same person, otherwise such instrument's ability to function effectively as an internal CGM would be severely curbed. Indeed, by serving simultaneously in both positions, a CEO would exert too much stature and influence

\footnotetext{
${ }^{1}$ Congestion in the decision process could cause a reduction in the board of directors' power, leaving the firm's management with major discretion.
} 
on board's members and on their capability to monitor managerial actions in an independent manner (Sundaramurthy et al., 1997). Of course, a board aligned to management interests would try to protect them from the risk of a takeover, attempting to reduce the action of an external CGM such as the market for corporate control. On the contrary, a board aligned to shareholders' interests would always try to maximize the deal's expected value.

\section{The Role of the Integration Manager in the Context of an International Acquisition}

This paper aims to clarify the role of the integration manager within the acquiring firm's board of directors. In this perspective, we offer an overview of the literature on integration managers.

Whereas only in the last two decades consulting firms have started to suggest the use of integration teams in order to smooth the merging process between the acquiring and acquired firms (Ashkenas et al., 1998; Ashkenas and Francis, 2000; Shelton, 2003), empirical investigation and theoretical modeling regarding these teams are still scant (Dagnino and Pisano, 2008; Teerikangas et al., 2011; Meglio et al., 2015). The importance of appointing integration managers to guide acquisitions was already recognized in the 1980 s with some academics discussing the crucial role of a specific team in charge of smoothing the different stages of the acquisition process (Dionne, 1988; De Noble et al., 1988). Teerikangas et al. (2011) support such view providing empirical evidence of the integration manager's role by analyzing several cases of cross-border acquisitions. They found that, in most of the examined acquisitions, integration managers affected the results by helping synergies and avoiding value leakage. More specifically, by individuating some specific roles - the change agent, staff mobilizer, and knowledge promoter roles - they elucidated the way such manager can align the conflicting demands originating from both the acquirer and the acquired side. 
Indeed, from an agency theory perspective, the integration manager's multifaceted role seems to consistently help the new entity to achieve a new and positive equilibrium.

In order to cover her/his role, this individual should: a) possess specific technical competences; b) have knowledge of the products/services and of the market of the acquired firm; c) and own substantial experience of the targeted industry. This latter aspect may reveal crucial especially with regard to international acquisitions, wherein cultural differences among dissimilar countries may have a critical impact on the deal's ultimate performance (Ahammad et al., 2016; Sarala et al., 2014; Datta and Puia, 1995); and, at general level, with regard to the degree of relatedness of acquisitions, which might require the need of local experience within an industry with which the acquirer might be unfamiliar (Bettis, 1981; Chatterjee et al., 1992).

Combined with these technical features, the integration manager should also show elements of personality and character resembling those of a transformational leader (Conger and Kanungo, 1987; Van de Ven, 1986; Bass, 1985). For instance, by analyzing the role of team leaders in supporting ambidexterity within acquisitions, Nemanich and Vera (2009) examined integration managers specifically focusing on their transformational leadership behaviors. They contended that, being acquisitions a dynamic context seriously challenging a current status quo, their success requires the guide of a transformational leader, that is someone who has a vision and is inspirational, charismatic and intellectually stimulating for those involved in the integration process. Such peculiarities of transformational leadership appear to be crucial in the context of an integration process. In fact, they seem to be useful in order to win the skepticism and distrust typically gripping acquired human resources, helping them to identify with the new entity's course of action and to develop a common and unique identity (Smith et al., 2013). In other words, to achieve human resources' trust and respect stimulating their full commitment to the new course, they need to be led by a leader who is 
able to implement a restructuring process organized to capture the value of the combining firms, achieving the best output from the two firms' complementary assets and capabilities (Antila, 2006). Indeed, restructuring is one of the most typical integration mechanism employed by acquiring firms in order to eliminate redundancies, reduce costs and exploit synergies through coordination. This is a crucial phase able to destroy value and therefore feared by those involved in the process. When restructuring creates uncertainty among employees, the risk of turnover and loss of crucial capabilities is extremely high (Larsson and Finkelstein, 1999; Ranft and Lord, 2000; Zhang et al., 2015). Hence, it is in this phase that the integration manager has to prove her/his transformational leadership qualities, being able to clearly communicate her/his ideas of the way s/he is going to integrate the two firms (Ullrich and van Dick, 2007). The same applies when the integration manager has to form and lead the transition teams. As another typical integration mechanism (Meglio et al., 2015), transition teams need to include individuals from both integrating entities in order to bring multiple perspectives and experiences to the merging process. The heterogeneity of such perspectives and experiences should help the new entity in identifying the best solutions for achieving synergies and detecting areas of improvement under the coordination ability of the integration manager. Such human resources' integration seems to play a central role for the success of acquisitions (Correia et al., 2013). Therefore, once vested of the legitimacy of such role, the integration manager would be in charge of leading the acquired firm, representing the acquirer's interests within the subsidiary, having care to manage the integration process in order to reach the acquirer's objectives.

Among the roles individuated in the integration manager's theoretical framework (Dagnino and Pisano, 2008), special mention has to be done for the organizational buffer's role. It relates to the network of relationships s/he has with both the board of the acquirer and the management of the acquired firm. Whether, on the one side, s/he is in charge of 
implementing the objectives and strategic guidelines received by the acquirer's board, s/he needs to filter the pressures on the other. Indeed, the board bears continuous pressure from shareholders asking for the financial results of their investment. Being the board composed of those same managers who proposed the deal, and being it the CGM that approved the acquisition, it is likely that there will be a constant request for results even after a short time from the deal's closure. Such pressure represents a serious risk of compromising the all integration activity. Managers who are working to exchange their knowledge and achieve synergies cannot be stressed and put under pressure with a constant request for results. Therefore, it is the integration manager who needs to filter such pressures and use all her/his network capabilities and communication skills in order to protect the integration process.

\section{Conceptual Development: Co-Opting The Integration Manager within the Acquiring}

\section{Firm's Board of Directors}

Usual steps when adopting a qualitative research include the collection and analysis of available data, the emerging conceptual categories with the connected structures and frameworks, and then the link for theoretical development. Notwithstanding that, in order to simplify the reader's comprehension of our case study, we decided to start by illustrating the conceptual development of the benefits of co-opting the integration manager within the acquiring firm's board of directors and interpreting the theoretical implications of our case later (Suddaby, 2006; Moschieri, 2011).

In view of the complexity of her/his role, no doubt the integration manager needs to be legitimated from above in order to attempt many different tasks and achieve everybody's commitment. In fact, being a mediator between the board of the acquirer and the management of the acquired firm, s/he needs to develop a trustable image at the eyes of the beholders. More specifically, both sides need to trust her/his activity and competence: to get 
everybody's trust, on the acquirer's side, the board needs to officially vest her/him of the necessary legitimacy, empowering such manager of a leading role within the firm, and approving/following her/his intuitions at both strategic and organizational level; on the acquired firm side, managers need to identify such manager with someone to trust, someone able to provide a solution to any arising problem and, most of all, someone who is retained extremely competent both in terms of the product/market and its technical aspects. This latter characteristic is very important, as people in the acquired firm would always rely on the integration manager's suggestions, as s/he would be competent of the product, thereby knowing how to develop or improve its performance (Dagnino and Pisano, 2008). Moreover, s/he knows the market; thus, s/he knows its customers with their own preferences, the competitors with their alternative offers, and the suppliers with their different strengths and weaknesses. Such manager's "global" knowledge is of extreme importance to our work that, as we anticipated, is contextualized with a primary focus on privately owned firms (Dagnino and Pisano, 2008).

Even though we lack of a wide literature on the role of boards of directors within privately owned firms, we can certainly ascertain that, in such context, their monitoring role in contrast to publicly held firms - is sensibly minimized, as owners and managers tend to coincide (Cannella and Galvagno, 2002). This means that the control role of the board is less dominating compared to its counseling role. Undeniably, when a single individual or a family controls a major block of stocks or even the majority of the shares, the power of both directors and managers is considerably reduced (Zald, 1969). In the context of privately owned firms, power is centralized as much as for widely dispersed ownership situations. Thus, even though the "forms" of board's actions are kept in order to satisfy legal obligations, the board serves at the discretion of the controlling owners. This means that its monitoring role is mostly deleted becoming a mere ratification task; whereas, instead, it is the 
consulting role that is maintained still active. It is for this reason - and because of the necessity to provide this individual with a legitimated position inside the whole firm - that the integration manager should be framed as a member of the board of directors. Herein, $\mathrm{s} / \mathrm{he}$ could help executives by participating to the strategy process and contributing with her/his knowledge of the product/service, market and country, particularly in the context of crossborder acquisitions. In this sense, Leksell and Lindgren (1982) stressed that firms emphasizing the board's external role tend to structure it around local outside directors who are well connected in the subsidiary's country - a crucial specificity that is perfectly resembled by our case study.

Following McDonald et al. (2008) suggestions with regard to board composition in acquisitions, we suggest that the integration manager may be the individual who, if introduced in the acquirer's board, could improve its capabilities through the necessary knowledge and expertise. More specifically, McDonald et al. (2008) contend the importance of directors who possess such expertise in the context of related acquisitions. However, when acquisitions are of cross-border nature, such expertise might become even more crucial given the heterogeneities of the two related industries and of the countries wherein the two merging entities operate. Moreover, as stressed by Coff (1999) who examined uncertainty in the case of acquisitions within knowledge-intensive industries, this industry typology combined with an international acquisition may suggest the identification of a local individual as integration manager to provide such knowledge and allow the merger of a higher likelihood of success.

However, a key aspect remaining unsolved regards the origin of the integration manager. Previous studies have considered three possible options (Dagnino and Pisano, 2008). The first option is selecting an individual who was previously working in the acquired firm. The advantages of such choice could be the degree of trustworthiness s/he would inspire in the acquired firm's managers, and the knowledge of the firm's product and market s/he 
would possess if compared to an outsider. The disadvantages of such choice would mainly relate to her/his motivation. In fact, nobody can be sure of her/his emotive status before being appointed to such crucial role.

The second option is selecting an individual who was previously working in the acquiring firm. The potential advantage of such choice is connected to the integration manager's knowledge of the acquiring firm's objectives and culture. Herein, s/he would exactly know what results to reach and what managing style the acquiring board would prefer. However, the risk of this choice relates to the probability of acceptance of such figure within the acquired firm. In order to improve the chance of acceptance, the board should be careful in choosing an individual with strong empathy and communication skills, legitimating her/his position at the eyes of the all stakeholders.

The third option is selecting the integration manager as an outsider to both firms, as it occurred in our case study. In such case, the lack of relationships with both firms' individuals should be compensated by a strong experience of the industry and a brilliant combination of skills and competences in order to capture everybody's trust and respect.

\section{INSERT HERE FIGURE 1}

\section{Methods}

According to Yin (1994), the case study research approach is a "to be preferred way" of reconnoitering the "how" and "why" questions referred to a phenomenon occurring in reallife contexts (Eisenhardt, 1989; Miles and Huberman, 1994; Eisenhardt and Graebner, 2007; Reddy, 2015). In this paper, the purpose of our case study is to explore whether the role of the "integration manager" as an additional CGM enhancing the effectiveness of the board of directors can positively affect the performance of an acquisition. 
Sample case

We conducted a case study about an acquisition regarding an Italian and a Spanish firm in the telecommunication industry. We named the acquirer 2PM SpA and the acquired firm Espanola SA (firms' real denominations were disguised for privacy reasons). The selection of a case study should be grounded on its relevance for investigation aims instead of statistical reasons (Pettigrew, 1990; Golden-Biddle and Locke, 1993). Indeed, the case we are going to present exhibits some aspects we considered crucial for our analysis. First, it is a case of cross-border acquisition in a related industry; this helps us to avoid any difficulties due to industry differences, as widely stressed by managerial literature (the debate of related vs. conglomerate acquisitions) (Bettis, 1981; Haspeslagh and Jemison, 1991). Second, the two merging firms' countries are in the same cluster following Hostfede's and Globe studies (Hofstede, 1980, 1991; House et al., 2004) helping us to avoid any difficulties due to the risk of cultural clashes. Third, the deal can be classified as a friendly acquisition, allowing us to examine the development of each process without the biases determined by the acquired firm's resistance to the deal's positive closure (Teerikangas et al., 2011). Fourth, we selected a case whose data could be verified in the years following the deal's closure helping us avoid any risk of naïve short-term evaluations (Schoenberg, 2006). Finally, we selected a specific case study wherein we ascertained the presence of an integration manager vested of the leadership of the integration process (Dagnino \& Pisano, 2008).

\section{Case description}

The acquirer was a medium-sized firm with a turnover of Euro 215 million and 2,780 employees. Even if directed by a top management team, 2PM SpA was under the control of Ciltel SpA, the family holding firm. Over the last two decades, its expansion in the ICT industry occurred primarily through greenfield investments, domestic acquisitions and 
strategic alliances. Since 1998, the firm became one of the most important players in the Italian telecommunication industry. By 2008, with the horizontal acquisition of Espanola SA, a Spanish firm operating in the same business, 2PM strengthened its position in the European telecommunication market. The due diligence process and the first post-acquisition phase have been supervised and monitored by the 2PM's board of directors by means of a Spanish top manager who has been appointed as a member of the board. Such manager, previously neither working for the Espanola SA nor for 2PM SpA, can be seen as an "integration manager". Essentially, the integration manager is an outsider who was selected because of her/his industry experience, her/his previous relationships with both firms, and her/his local connections at both political and institutional level. The importance of this last point is dramatic. In fact, being it a cross-border acquisition, getting local legitimacy was required to avoid potential obstructions at country-level.

\section{Data collection and analysis}

We collected data at the acquirer's headquarters for approximately one year, starting in early 2007. Our primary data sources were twofold: archives and interviews. We started to collect data by gathering extensively from both internal and external sources: the former included internal reports and presentations; the latter included media articles regarding the two firms involved in the deal.

We perpetuated data collection by means of semi-structured interviews. After the acquisition, we interviewed multiple senior-level informants from both firms (see Table 1 for a list of the interviewees' positions within the two firms). The pilot interviews guided our identification of the informants who were the most influential in the acquisition process.

PLEASE INSERT TABLE 1 ABOUT HERE 
The use of multiple informants mitigates subject biases and allows us the triangulation of facts (Miller et al., 1997) leading to richer and more convincing findings (Schwenk, 1985). The open-ended protocol allowed us to seek for further information and probe unanticipated insights (Yin, 1994). We used such interviews in order to identify major decisions regarding the acquisition of the target firm, which then we combined with those previously identified in the archival information triangulating data. We ended data collection process once a sufficient level of saturation was achieved (Glaser and Strauss, 1967).

The interview guide was organized in two main sections. The first one was made of open-ended questions providing informants with an extensive view of both buyer and target businesses. The second section focused on specific questions about the acquisition process and its governance issues. Examples of questions included: "when did you first begin thinking about the acquisition?"; "what was your first reaction about the M\&A?"; "has your reaction changed after some time?"; "and, if yes, why?"; "what potential integration manager did you consider?"; "what kind of interactions did you have with the integration manager?"; "why did you decide to include the integration manager within the board of directors?"; "what was the impact of the integration manager in the decision making process?"; "what is the weight you would attribute to the integration manager's intervention?".

The interviews ranged from about one to two hours length.

On the basis of Reddy et al. (2015), Table 2 summarizes the main features of the case study protocol.

PLEASE INSERT TABLE 2 ABOUT HERE

\section{Case Analysis and Discussion}

The Preexisting Structure of the Acquiring Firm 
According to the policy of the acquiring firm, board members and top managers are entitled to own some shares of the firm. Thus, in addition to the board, the executive compensation system serves also as an effective CGM aligning shareholders and top management interests. According to the CEO, stock option plans contribute to enhance managers' commitment to the firm.

Since 2002, the acquiring firm has primarily grown within its domestic market without overlooking international arenas: for instance, some divisions were opened in Northern Africa and Eastern Europe. Even if moderate, the international expansion has also been strengthened via strategic alliances with notable players of the telecommunication industry.

According to the strategic plan formulated by the CEO for the time horizon 20082012 - approved by the board in order to expand the business scope - the firm decided to significantly encourage its international strategy through a cross-border acquisition. The firm identified one of the most important players in the Spanish telecommunication market temporarily facing some financial constraints - and targeted it for an international horizontal acquisition.

The friendly acquisition involved a Spanish target that was a medium-sized firm (180 employees with revenues accounting for more than $€ 42$ millions) owned by a large-block shareholder. As usual, the legal and financial due diligence for this business transaction was delegated to a leading consulting firm, even though assigned to the firm's Spanish branch, since it possessed specific knowledge of domestic procedures.

The acquirer was primarily concerned with harmonizing organizational and cost accounting procedures between the two merging firms; the top management replacement was only restricted to the acquired firm's CEO, who resigned. 
Finally, the board of directors selected an external top manager for the integration manager's position in order to facilitate the post-acquisition integration process. He was an external manager with M\&A expertise.

The due diligence and post-acquisition processes were supervised and monitored by the board of directors by the means of a Spanish top manager, who was contextually appointed as member of the board. Such manager, previously working neither for the acquirer nor for the acquired firm (not for the consulting firm), was described as the acquiring firm's integration manager. While the integration manager was external to the negotiation process, he was the protagonist of the business combination. When the two firms defined the price for the acquisition, the integration manager was called for managing the combination process between the two firms, for instance the negotiation with labor unions. Interestingly, the selected top manager had a positive reputation in Spain. All of these attributes were told to be very relevant for the entrant's acquisition strategy (Teerikangas et al., 2011). Indeed, the integration manager acted as delegate of the acquirer's board and possessed skills, information and legitimacy that facilitated the integration process (Teerikangas et al., 2011). Overall, the integration manager was involved in the planning and implementation processes (Teerikangas et al., 2011).

\section{Findings}

The integration manager is a Spanish top manager that 2PM previously met several times, due to her/his great experience about the Spanish telecommunication market and its domestic customers. S/he had a great reputation as s/he was well known in Spain. All these features can be considered relevant for the 2PM's acquisition strategy. Indeed, such manager acted as a delegate of the acquirer's board and possessed skills, information, and the legitimacy to facilitate the acquisition process. In addition, being it an international acquisition, s/he was 
not seen from the acquired firm's employees as a foreign manager of the acquirer who could take advantage of the transaction. Finally, due to her/his expertise, s/he might be considered as a "transformational leader".

Evidence revealed the pivotal role of the integration manager in ensuring the acquiring firm's better entry into the new country. In our case study, the integration manager was specifically hired from the Spanish environment. Our finding that $\mathrm{s} / \mathrm{he}$ was central to the firm's acquisition performance is strongly consistent with other studies identifying the choice of a local "champion" as crucial in leading acquisition processes (Dagnino and Pisano, 2008). Indeed, selecting an integration manager who is alien to both organizations indicates the choice of the buyer to opt for the employment of an impartial managerial figure. Even if initially classifiable as a negative aspect, the lack of relationships with both firms' individuals should though be compensated by a strong industry experience and an excellent combination of skills and competences in order to capture everybody's trust and respect. In the words of the buying firm's CEO: “The choice of a Spanish manager was strategically important to us. It helped us to create a positive atmosphere by the time of our first visits to the target." In particular, the acquiring firm leaders viewed the choice of a Spanish manager as an opportunity to accrue substantial knowledge of the acquired firm's products/services and of its market; moreover, it was a quicker way to achieve such knowledge, compared to what it could have occurred if the same objectives were to be accomplished through internal solutions. As a business development executive at acquiring firm commented: "Being able to quickly develop the broadest knowledge of the market regarding the acquired firm was crucial to us." Moreover, the integration manager's commonly recognized experience and expertise helped the entrant to be accepted within the local context, avoiding the typical uncertainty and fear characterizing the first 100-days following the deal's closure (Singh and Montgomery, 1987). As affirmed by one of the team managers involved in the due diligence 
process, such a decision was taken very carefully and was based on the firm's previous experience in other domestic deals: "As this was not our first acquisition, we had certain knowledge of the process. In particular, we were conscious of how important the first occasions are wherein you get introduced to the target firm's environment. The possibility to be walked in by a local and well-respected manager-formally invested of an important managerial role - gave us the opportunity to enter the room with the right foot."

After the completion of the negotiation process, the integration manager's expertise revealed to be very critical. Thus, the acquiring firm almost immediately decided to co-opt the integration manager by placing him/her within the board of directors. As stated by the acquiring firm's CEO: “Deciding to give this person a dedicated position inside the board served as a clear message, publicly advertising our commitment in the eyes of the target firm's environment." This choice further entrenched management relations, giving the integration manager the opportunity to directly interact with the top-level decision makers.

Although the Spanish telecommunication industry was not unknown to the acquirer's management, the aid of a local individual - directly involved in the strategy-making process and very well networked at local level - was tremendously fruitful in terms of her/his advices provided along the process. In the words of one of the board members: "The presence of the integration manager inside the board of directors gave us the possibility to examine influential information before approving the implementation of our market-entering strategy. Such support revealed to be an authentic advantage in explaining from an inside perspective various peculiarities of the Spanish environment we could have never known by ourselves".

For instance, the integration manager's personal contacts with a local financial institution revealed to be very useful in implementing the firm's financial plan. Moreover, her/his personal acquaintance with one of the major leaders of a local labor union opened up a new set of potential solutions in human resource management, smoothing the acquirer's 
entering strategy. In the words of an acquired firm's manager: "I remember that meetings became immediately intense by the time of the first negotiations. For instance, if the deal was to go through, there were a few but quick decisions to take in order to avoid lay-offs. Well, I can affirm that after a couple of meetings between a few of us, the new Spanish manager and some representatives of labor unions, we had already unraveled our major doubts".

And in the words of another acquired firm's manager: "One of the pillars of our previous internal policy was trying to always favor domestic suppliers. Therefore, after the deal's closure, one of the main strategic issues on the table was how to reorganize our supply chain. I remember that the acquiring firm's $C E O$ was extremely resolute regarding this issue: he basically said that, before the decision's approval, the proposal had to be $100 \%$ left to the new local manager, as s/he benefited of the complete trust of the board in finding the best solutions within the network of her/his personal contacts. And that's exactly what happened".

Our study shows that the integration manager was very helpful to the acquirer during the all acquisition process. S/he was given the legitimacy to make some important decisions, such as those concerning the downsizing and down-scoping strategies of the target firm. Indeed, the integration manager neither laid-off employees nor changed completely the strategy of the acquired firm. Instead, s/he primarily acted as an organizational filter between the acquirer and the acquired firm, in the attempt to slowly align their firms' cultures and cost management procedures.

Furthermore, s/he facilitated the acquisition process by making use of her/his position as member of the board of directors. Our study shows that the external manager hired by 2PM SpA to facilitate the acquisition process was invited by the acquiring firm's CEO to take a seat as a member of the 2PM's board of directors. Once the acquisition process was completed, s/he was no longer an outside member of the board, but began to serve as an insider, acting as a delegate of 2PM SpA within the acquired firm. According to the Chair of 
the board, the appointment of the integration manager as a director enhanced significantly the effectiveness of 2PM's board of directors, making the governance devices more effective in the alignment of shareholders and managers' interests. The results of the post-acquisition integration phase are smooth and soon the acquired firm will change its name into 2PM Spain.

\section{Conclusions}

Notwithstanding their strategic relevance in real life practice, the role of integration managers is still overlooked by acquisition scholars (Meglio et al., 2015). Even if the results of our exploratory study cannot be easily generalized and extended to a larger number of firms (also in different industries and with alternative ownership structures), this paper highlighted the importance of additional tools enhancing the effectiveness of traditional governance devices used to align shareholders and managers' interests.

Drawing on corporate governance and international management literature, this paper focuses on the integration manager employed to strengthen the success of post-acquisition processes and to mitigate the difficulties due to the presence of entry barriers. Indeed, this paper demonstrated that, despite the fact that privately held companies are monitored and controlled by their owners, the effectiveness of the board in counseling and directing the most important strategic decisions is significantly enhanced when these firms appoint an integration manager as board director. Indeed, while facilitating the integration process of the acquired firm, s/he represents a tie with the board of the acquirer wherein s/he takes a seat.

In this paper, we emphasized the relevance of such CGMs even in privately held firms, which apparently cope with few agency problems due to their concentrated ownership structure. Indeed, this paper demonstrated that, even though private firms with high level of ownership concentration were daily monitored and controlled by the owner, the effectiveness 
of the board in counseling and directing the most important strategic decisions may be significantly enhanced when, going internationally, firms appoint an integration manager as a new director. Therefore, this paper shows at both theoretical and empirical level that the integration manager might be an additional tool significantly enhancing the effectiveness of traditional CGMs - primarily the board, ownership concentration and executive compensation - to better serve shareholders' interests.

The provided study demonstrated that, going internationally through acquisitions, even if apparently less risky than greenfield investments, may require additional neutral information flow - within both the due diligence process and the post-acquisition integration - that only outsiders possess. Such outsiders have been individuated in the integration manager whose role in smoothing the pre- and post-acquisition integration processes was described. When appointed as a member of the board, the outsider becomes an insider if s/he is in charge to also run the acquired firm. Acting in such a way, any potential divergences between the principal and agent are eliminated even in those firms, like family-owned ones, that by definition encounter some agency problems.

\section{Managerial Implications}

This paper theoretically develops the idea of introducing the integration manager within the acquiring firm's board of directors, showing her/his empirical contribution to the performance of acquisitions (Teerikangas et al., 2011). Drawing on our findings, it is promising to discern some insights that may guide executives in the deployment of resources (Roth, 1995) and introduce CGMs that epitomize successful cross-border acquisitions.

First, our paper emphasizes the risks underlining the choice to go internationally through acquisitions; thus, it stresses the relevance of the information flows necessary for an effective due diligence process. 
Second, the proposed role of the integration manager within the acquiring firm's board of directors appears to be critical for entrenched organizational relations, allowing her/him to cooperate with the top-level decision makers.

Third, this paper proposes a managerial innovation in managing firms' growth via internationalization, i.e., to revitalize the board of directors after a cross-border acquisition. However, "being aware of the integration manager's roles, organizations engaging in [crossborder] M\&A are better positioned with regard to the tasks and activities assigned to the integration manager. This understanding can further serve as a means of selecting the integration manager - is the person capable of [covering such] roles?" (Teerikangas et al., 2011: 679). 
References

Aguilera, R.V. and Dencker, J.C. (2004), "The role of human resource management in crossborder mergers and acquisitions", International Journal of Human Resource Management, Vol. 15 No 8, pp. 1355-1370.

Ahammad, M.F., Tarba, S.Y., Liu, Y. and Glaister, K.W. (2016), "Knowledge transfer and cross-border acquisition performance: the impact of cultural distance and employee retention". International Business Review, Vol. 25 No. 1A, pp. 66-75.

Aharoni, Y., Tihanyi, L. and Connelly, B.L. (2011), "Managerial decision-making in international business: A forty-five-year retrospective", Journal of World Business, Vol. 46 No. 2, pp. 135-142.

Angwin, D. (2001), "Mergers and acquisitions across European borders: National perspectives of preacquisition due diligence and the use of professional advisers", Journal of World Business, Vol. 36 No.1, pp. 32-57.

Antila, E. (2006), "The role of HR managers in international mergers and acquisitions: a multiple case study", International Journal of Human Resource Management, Vol. 17 No. 6, pp. 999-1020.

Ashkenas, R.N., DeMonaco, L.J., and Francis, S.C. (1998), "Making the deal real: How GE Capital integrates acquisitions", Harvard Business Review, Gen.-Feb., 165-178.

Ashkenas, R.N., Francis, S.C. (2000), "Integration managers: Special leaders for special times", Harvard Business Review, Vol. 78 No. 6, pp. 108-116.

Aureli, S. (2015), "Performance of unlisted Italian companies acquired by multinationals from emerging markets", Journal of Organizational Change Management, Vol. 28 No. 5, pp. 895 - 924.

Baliga, B.R., Moyer, R.C. and Rao, R.S. (1996), "CEO duality, firm performance and corporate governance", Strategic Management Journal, Vol. 17 No. 1, pp. 41-53.

Bange, M.M. and Mazzeo, M.A. (2004), "Board composition, board effectiveness, and the observed form of takeover bids", Review of Financial Studies, Vol. 17 No. 4, pp. 1185-1215.

Barnhart, S.W., Marr M.W. and Rosenstein, S. (1994), "Firm performance and board composition: Some new evidence", Managerial and Decision Economics, Vol. 15 No. 4, pp. 329-340.

Barthala, C.T. and Rao, R.P. (1995), "The determinants of board composition: An agency theory perspective", Managerial and Decision Economics, Vol. 16 No. 1, pp. 59-69.

Bass, B.M. (1985), Leadership and performance beyond expectations, Free Press, New York, NY.

Bettis, R.A. (1981), "Performance differences in related and unrelated diversified firms", Strategic Management Journal, Vol. 2 No. 4, pp. 379-393.

Bing, G. (2008), Due diligence: planning, questions, issues. Praeger Publishers, Westport, CA.

Birkinshaw, J.M. and Morrison, A.J. (1995), "Configurations of strategy and structure in subsidiaries of multinational corporations", Journal of International Business Studies, Vol. 26 No. 4, pp. 729-753.

Björkman, I., Stahl, G.K. and Vaara, E. (2007), "Cultural differences and capability transfer in cross-border acquisitions: The mediating roles of capability complementarity, absorptive capacity, and social integration", Journal of International Business Studies, Vol. 38 No. 4, pp. 658-672.

Canabal, A. and White III, G. O. (2008), "Entry mode research: Past and future", International Business Review, Vol. 17 No. 3, pp. 267-284. 
Cannella, A.A. and Galvagno, M. (2002), Governance and control for firms in transition, in Schillaci, C.E. and Faraci, F. (ed.), The ownership and governance of firms in transition: The Italian experience. Giappichelli, Torino, IT, pp. 21-46.

Carpenter, M.A. and Westphal, J.D. (2001), "The strategic context of external network ties: Examining the impact of director appointments on board involvement in strategic decision making", Academy of Management Journal, Vol. 44 No. 4, pp. 639-660.

Certo, S.T. (2003), "Influencing initial public offering investors with prestige: Signaling with board structures", Academy of Management Review, Vol. 28 No. 3, pp. 432-446.

Charkham, J. (1994), Keeping good company: A study of corporate governance in five countries, Clarendon Press, Oxford, UK.

Chatterjee, S., Lubatkin, M.H., Schweiger, D.M. and Weber, Y. (1992), "Cultural differences and shareholder value in related mergers: Linking equity and human capital", Strategic Management Journal, Vol. 13 No. 5, pp. 319-334.

Coff, R.W. (1999), "How buyers cope with uncertainty when acquiring firms in knowledgeintensive industries: Caveat emptor", Organization Science, Vol. 10 No.2, 144-161.

Cohen, B.D. and Dean T.J. (2005), "Information asymmetry and investor valuation of IPOs: Top management team legitimacy as a capital market signal", Strategic Management Journal, Vol. 26 No. 7, pp. 683-690.

Coles, J.L. and Hesterly, W.S. (2000), "Independence of the chairman and board composition: Firm choices and shareholder value", Journal of Management, Vol. 26 No. 2, pp. 195-214.

Conger, J.A. and Kanungo, R.N. (1987), "Toward a behavioral theory of charismatic leadership in organizational settings", Academy of Management Review, Vol. 12 No. 4, pp. 637-647.

Correia, M., Cunha, R. and Scholten, M. (2013), "Impact of M\&As on organizational performance: the moderating role of HRM centrality", European Management Journal, Vol. 31 No. 4, pp. 323-332.

Cotter, J.F., Shivdasani, A. and Zenner, M. (1997), "Do independent directors enhance target shareholder wealth during tender offers?" Journal of Financial Economics, Vol. 43 No. 2, pp. 195-218.

Cullinan, G., Le Roux, J.-M. and Weddigen, R.-M. (2004), "When to walk away from a deal", Harvard Business Review, Vol. 82 No. 4, pp. 96-105.

Dagnino, G.B. and Pisano, V. (2008), Unpacking the champion of acquisitions: The key figure in the execution of the post-acquisition integration process, in Cooper, C. and Finkelstein, S. (ed.), Advances in Mergers and Acquisitions Vol. 7, Emerald Group Publishing Limited, pp. 51-69.

Dagnino, G.B., Giachetti, C. La Rocca, M. and Picone, P.M. (2014) "Unveiling the antecedents of international diversification: An agency theory approach", Academy of Management Proceedings, Philadelphia, pp.1126-1131.

Daily, C.M. and Dalton, D.R. (1994), "Bankruptcy and corporate governance: The impact of board composition and structure", Academy of Management Journal, Vol. 37 No. 6, pp- 1603-1617.

Datta, D. and Puia, G. (1995), "Cross-border acquisitions: An examination of the influence of relatedness and cultural fit on shareholder value creation in U.S. acquiring firms", Management International Review, Vol. 35 No. 4, pp. 337-359.

Dauber, D. (2012), "Opposing positions in M\&A research: culture, integration and performance", Cross Cultural Management, Vol. 19 No. 3, pp. 375-398.

De Noble, A., Gustafson, L. and Hergert, M. (1988), "Planning for post-merger integration: eight lessons for merger success", Long Range Planning, Vol. 21 No. 4, pp. 82-85. 
Deiser, R. (1994), "Post-acquisition management: A process of strategic and organizational learning", in Von Krog, G., Sinatra, A. and Singh, H. (Ed.), The management of corporate acquisitions, MacMillan Press, New York, NY.

Dionne, J. (1988), “The art of acquisitions", Journal of Business Strategy, Vol. 9 No. 6, pp. 13-17.

Eisenhardt, K.M. (1989) "Building theories from case study research", Academy of Management Review, Vol. 14 No. 4, pp. 532-550.

Eisenhardt, K.M. and Graebner, M.E. (2007), "Theory building cases: opportunities and challenges", Academy of Management Journal, Vol. 50 No. 1, pp. 25-32.

Epstein, M.J. (2004), "The drivers of success in post-merger integration", Organizational Dynamics, Vol. 33 No. 2, pp. 174-189.

Fama, E.F. and Jensen, M.C. (1983), "Separation of ownership and control", Journal of Law and Economics, Vol. 26 No. 2, pp. 301-325.

Forbes, D.P. and Milliken, F.J. (1999), "Cognition and corporate governance: Understanding board of directors as strategic decision-making groups", Academy of Management Review, Vol. 24 No. 3, pp. 489-505.

Glaser, B.G. and Strauss, A.L. (1967), The discovery of grounded theory: strategies for qualitative research, Aldine, Chicago, IL.

Golden, B.R. and Zajac, E.J. (2001), "When will board influence strategy? Inclination x Power = Strategic Change", Strategic Management Journal, Vol. 22 No. 12, pp. 1087-1111.

Golden-Biddle, K. and Locke, K. (1993), "Appealing work: An investigation of how ethnographic texts convince”, Organization Science, Vol. 4 No. 4, pp. 595-616.

Harding, D. and Rouse, T. (2007), Human due diligence. Harvard Business Review, Vol. 85 No. 4, pp. 124-131.

Harford, J. (2003), “Takeover bids and target directors' incentives: The impact of a bid on a director's wealth and board seats", Journal of Financial Economics, Vol. 69 No. 1, pp. 51-83.

Harvey, M.G. and Lusch, R.F. (1995), "Expanding the nature and scope of due diligence", Journal of Business Venturing, Vol. 10 No. 1, pp. 5-21.

Haspeslagh, P.C. and Jemison, D.B. (1991), Managing acquisitions: creating value through corporate renewal. The Free Press, New York, NY.

Hayward, M. and Hambrick, D. (1997), "Explaining the premiums paid for large acquisitions: Evidence of CEO hubris", Administrative Science Quarterly, Vol. 42 No.1, pp. 103-27.

Higgins, M.C. and Gulati, R. (2006), "Stacking the deck: The effects of top management backgrounds on investor decisions", Strategic Management Journal, Vol. 27 No. 1, pp. 1-25.

Hillman, A.J. \& Dalziel, T. (2003), "Boards of directors and firm performance: integrating agency and resource dependence perspectives", Academy of Management Review, Vol. 28 No. 3, pp. 383-396.

Hitt M.A. and Pisano, V. (2003), "The Cross-Border Merger and Acquisition Strategy: A Research Perspective", Management Research: Journal of the Iberoamerican Academy of Management, Vol. 1 No. 2 pp. 133 - 144

Hitt, M.A., Ireland, R.D. and Hoskisson, R.E. (2015), Strategic Management: Competitiveness and Globalization, Cengage Learning, Stamford, CT.

Hitt, M.A., Li, D. and $\mathrm{Xu}, \mathrm{K}$. (2016), "International strategy: From local to global and beyond", Journal of World Business, Vol. 51 No. 1, pp. 58-73.

Hitt, M.A., Tihanyi, L., Miller, T. and Connelly, B. (2006), "International diversification: Antecedents, outcomes, and moderators", Journal of Management, Vol. 32 No. 6, pp. 
831-867.

Hofstede G., (1991), Cultures and organizations: software of the mind, McGraw-Hill, London, U.K.

Hofstede, G., (1980), Culture's consequences: international differences in work-related values, Sage Publications, Beverly Hills, CA.

House R.J., Hanges P.J., Javidan M., Dorfman P., Gupta V., (2004), Culture, leadership, and organizations: the GLOBE study of 62 societies, Sage Publications, Thousand Oaks, CA.

Ibora, M. and Dolz C., (2006), "Consequences of Integration Heterogeneity in Mergers and Acquisitions", Management Research: Journal of the Iberoamerican Academy of Management, Vol. 4 No. 2, pp. 127 - 138

Iborra, M.C.S. (2004), "Choices in Joint Venture and Acquisition Negotiation Behavior: The Power-Dependence Relationship" Management Research: Journal of the Iberoamerican Academy of Management, Vol. 2 No. 3, pp. 219 - 234.

Jemison, D.B. and Sitkin, S.B. (1986), "Corporate acquisitions: A process perspective", Academy of Management Review, Vol. 11 No. 1, pp. 145-163.

Kaplan, S.N. and Weisbach, M.S. (1992), "The success of acquisitions: Evidence from divestitures", Journal of Finance, Vol. 47 No. 1, pp. 107-138.

Kisgen D.J. and Song, W. (2009), "Are fairness opinions fair? The case of mergers and acquisitions", Journal of Financial Economics, Vol. 91 No. 2, pp. 179-207.

Lajo, A. and Elson, C. (2010), The art of $M \& A$ due diligence: navigating critical steps and uncovering crucial data, McGraw Hill, New York, NY.

Larsson, R. and Finkelstein, S. (1999), "Integrating strategic, organizational, and human resource perspectives on mergers and acquisitions: a case survey of synergy realization", Organization Science, Vol. 10 No. 1, pp. 1-26.

Lebedow, A.L. (1999), "M\&A: due diligence: more than a financial exercise", Journal of Business Strategy, Vol. 20 No. 1, pp. 12-14.

Leksell, L. and Lindgren, U. (1982), "The board of directors in foreign subsidiaries", Journal of International Business Studies, Vol. 13 No. 1, pp. 27-38.

Mallette, P. and Fowler, K.L. (1992), "Effects of board composition and stock ownership on the adoption of «poison pills»" “, Academy of Management Journal, Vol. 35 No 5, pp. 1010-1035.

Malmendier, U. and Tate G. (2008), "Who makes acquisitions? CEO overconfidence and the market's reaction", Journal of Financial Economics, Vol. 89 No. 1, pp. 20-43.

Marks, M.L. and Mirvis, P.H. (2001), "Making mergers and acquisitions work: Strategic and psychological preparation", Academy of Management Executive, Vol. 15 No. 2, pp. 80-92.

McDonald, M.L., Westphal, J.D. and Graebner, M.E. (2008), "What do they know? The effects of outside director acquisition experience on firm acquisition performance", Strategic Management Journal, Vol. 29 No. 11, pp. 1155-1177.

Meglio, O., King, D.R. and Risberg, A. (2015), "Improving acquisition outcomes with contextual ambidexterity", Human Resource Management, Vol. 54 No. 1, pp. s29s43.

Michaely, R. and Womack, K.L. (1999), "Conflict of interest and the credibility of underwriter analyst recommendations", Review of Financial Studies, Vol. 12 No. 4, pp. 653-686.

Miles, M.B. \& Huberman, A.M. (1994), Qualitative data analysis: an expanded sourcebook, Sage Publishing, Thousand Oaks, CA. 
Miller, C.C., Cardinal, L.B. \& Glick, W.H. (1997), "Retrospective reports in organizational research: a reexamination of recent evidence", Academy of Management Journal, Vol. 40 No. 1, pp. 189-204.

Monks, R. and Minow, N. (1995), Corporate governance, Blackwell Business, Cambridge, MA.

Moschieri, C. (2011), "The implementation and structuring of divestitures: the unit's perspective", Strategic Management Journal, Vol. 32 No. 4, pp. 368-401.

Nahavandi, A. and Malekdazeh, A.R. (1988), "Acculturation in mergers and acquisitions", Academy of Management Review, Vol. 13 No.1, pp. 79-90.

Nahavandi, A. and Malekdazeh, A.R. (1994), "Successful mergers through acculturation", in Von Krog, G., Sinatra, A. and Singh, H. (Ed.), The management of corporate acquisitions, MacMillan Press, New York, NY.

Nemanich, L. and Vera, D. (2009), "Transformational leadership and ambidexterity in the context of an acquisition", Leadership Quarterly, Vol. 20 No. 1, pp. 19-33.

Nohria, N. and Ghoshal, S. (1994), "Differentiated Fit and Shared Values, Alternatives for Managing Headquarters-Subsidiary Relations", Strategic Management Journal, Vol. 15 No. 6, pp. 491-502.

Oesterle, M.J., Richta, H.N. and Fisch, J.H. (2013), "The influence of ownership structure on internationalization", International Business Review, Vol. 22 No. 1, pp. 187-201.

Perry J.S. and Herd, T.J. (2004), "Mergers and acquisitions: Reducing M\&A risk through improved due diligence", Strategy and Leadership, Vol. 32 No. 2, pp. 12-19.

Pettigrew, A. M. (1990), "Longitudinal field research on change: Theory and practice", Organization science, Vol. 1 No. 3, pp. 267-292.

Pfeffer, J. and Salancik, G.R. (2003), The external control of organizations: A resource dependence perspective, Stanford University Press, Stanford, CA.

Picone, P. M., Dagnino, G. B. and Minà, A. (2014), "The origin of failure: A multidisciplinary appraisal of the hubris hypothesis and proposed research agenda", Academy of Management Perspectives, Vol. 28 No. 4, pp. 447-468.

Porrini, P. (2006), "Are investment bankers good for acquisition premiums?", Journal of Business Research, Vol. 59 No. 1, pp. 90-99.

Puranam, P., Powell, B.C. and Singh, H. (2006), "Due diligence failure as a signal detection problem", Strategic Organization, Vol. 4 No. 4, pp. 319-348.

Ranft, A. and Lord, M. (2000), "Acquiring new knowledge: the role of retaining human capital in acquisition of high-tech firms", Journal of High Technology Management Research, Vol. 11 No. 2, pp. 295-319.

Rechner, P.L. and Dalton, D.R. (1991), "CEO duality and organizational performance: A longitudinal analysis", Strategic Management Journal, Vol. 12 No. 2, pp. 155-160.

Reddy, K. S. (2014), "Extant reviews on entry-mode/internationalization, mergers \& acquisitions, and diversification: Understanding theories and establishing interdisciplinary research", Pacific Science Review. Vol 16 No. 4, pp. 250-274.

Reddy, K. S. (2015), "Beating the Odds! Build theory from emerging markets phenomenon and the emergence of case study research-A "Test-Tube" typology", Cogent Business \& Management, Vol. 2 No. 1, pp. 1-25.

Reddy, K. S., Xie, E. and Agrawal, R. (2015), Revisiting and reinforcing the Farmers Fox Theory: A study (test) of three cases of cross-border inbound acquisition transactions. Pacific Science Review B: Humanities and Social Sciences, 1(1), 22-44.

Redor, E. (2015), "Board attributes and shareholder wealth in mergers and acquisitions: a survey of the literature", Journal of Management \& Governance, 1-33. 10.1007/s10997-015-9328-y

Roth K. and O'Donnell S. (1996), "Foreign subsidiary compensation strategy, an agency 
theory perspective", Academy of Management Journal, Vol. 39 No. 3, pp. 678-703.

Roth, K. (1995), "Managing international interdependence: CEO characteristics in a resource-based framework", Academy of Management Journal, Vol. 38 No. 1, pp. 200-231.

Sarala, R., Junni, P., Cooper, C. and Tarba, S.Y. (2014), "A sociocultural perspective on knowledge transfer in mergers and acquisitions", Journal of Management, Vol. 10 No. 3, pp. 496-503.

Schoenberg, R. (2006), "Measuring the Performance of Corporate Acquisitions: An Empirical Comparison of Alternative Metrics", British Journal of Management, Vol. 17 No. 4, 361-370.

Schwenk, C.R. (1985), "The use of participant recollection in the modeling of organizational decision processes", Academy of Management Review, Vol. 10 No. 3, pp. 496-503.

Seth, A., Song, K. P. and Pettit, R. (2000), "Synergy, managerialism or hubris? An empirical examination of motives for foreign acquisitions of US firms", Journal of International Business Studies, Vol. 31 No. 3, pp. 387-405.

Shelton, M. J. (2003), "Managing your integration manager", McKinsey on Finance, Summer, 12-15.

Shimizu, K., Hitt, M.A., Vaidyanath, D. and Pisano, V. (2004), "Theoretical foundations of cross-border mergers and acquisitions: A review of current research and recommendations for the future", Journal of International Management, Vol. 10 No. 3, 307-353.

Singh, H. and Montgomery, C. (1987), "Corporate acquisition strategies and economic performance", Strategic Management Journal, Vol. 8 No. 4, 377-386.

Smith, P., da Cunha, J.V., Giangreco, A., Vasilaki, A. and Carugati, A. (2013), "The threat of dis-identification for HR practices: An ethnographic study of a merger", European Management Journal, Vol. 31 No. 3, pp. 308-321.

Stahl, G.K. and Voigt A. (2008), "Do cultural differences matter in mergers and acquisitions? A tentative model and examination”, Organization Science, Vol. 19 No. 1, pp. 160176.

Stake, R.E. (1995), The art of case study research, Sage, Thousand Oaks, CA.

Suddaby, R. (2006), "From the editors: What grounded theory is not", Academy of Management Journal, Vol. 49 No. 4, pp. 633-642.

Sundaramurthy, C., Mahoney, J.M. and Mahoney, J.T. (1997), "Board structure, antitakeover provisions, and stockholder wealth", Strategic Management Journal, Vol. 18 No. 3, pp. 231-245.

Teerikangas, S., Véry, P. and Pisano, V. (2011), “Integration manager's value-capturing roles and acquisition performance", Human Resource Management, Vol. 50 No 5, pp. 651683.

Tihanyi, L., Johnson, R. A., Hoskisson, R. E. and Hitt, M. A. (2003), "Institutional ownership differences and international diversification: The effects of boards of directors and technological opportunity", Academy of Management Journal, Vol. 46 No. 2, pp. 195211.

Ullrich, J. and van Dick, R. (2007), "The group psychology of mergers and acquisitions: lessons from the social identity approach", in Cooper, C. and Finkelstein, S. (ed.), Advances in Mergers and Acquisitions Vol. 6, Emerald Group Publishing Limited, pp. 51-69.

Van de Ven, A.H. (1986), "Central problems in the management of innovation". Management Science, Vol. 32 No. 5, pp. 590-607. 
Very, P. and Schweiger, D.M. (2001), "The acquisition process as a learning process: Evidence from a study of critical problems and solutions in domestic and cross-border deals", Journal of World Business, Vol. 36 No. 1, pp. 11-31.

Walter, G.A. and Barney, J.B. (1990), "Management objectives in mergers and acquisitions", Strategic Management Journal, Vol. 11 No. 1, pp. 79-86.

Walters, B. A., Kroll, M. J. and Wright, P. (2007), "CEO tenure, boards of directors, and acquisition performance" Journal of Business Research, Vol. 60 No. 4, pp. 331-338.

Werner, S. (2002), "Recent developments in international management research: A review of 20 top management journals", Journal of Management, Vol. 28 No. 3, pp. 277-305.

Williamson, O.E. (1984), Corporate governance, Yale Law Journal, Vol. 93 No. 7, 11971230.

Yermack, D. (1996), "Higher market valuation of companies with a small board of directors", Journal of Financial Economics, Vol. 40 No. 2, 185-211.

Yin, R. (1994), Case study research: design and methods (2nd ed.), Sage Publishing, Thousand Oaks, CA.

Zald, M.N. (1969), "The power and functions of boards of directors: A theoretical synthesis", American Journal of Sociology, Vol. 75 No. 1, pp. 97-111.

Zhang, J., Ahammad, M.F., Tarba, S.Y., Cooper, C.L., Glaister, K.W. and Wang, J. (2015), "The effects of leadership style on talent retention during merger and acquisition integration: evidence from China", International Journal of Human Resource Management, Vol. 26 No. 7, pp. 1021-1050. 
Figure 1. The functions of the board in the context of internationalization strategies and the advantages of coopting the integration manager for their implementation
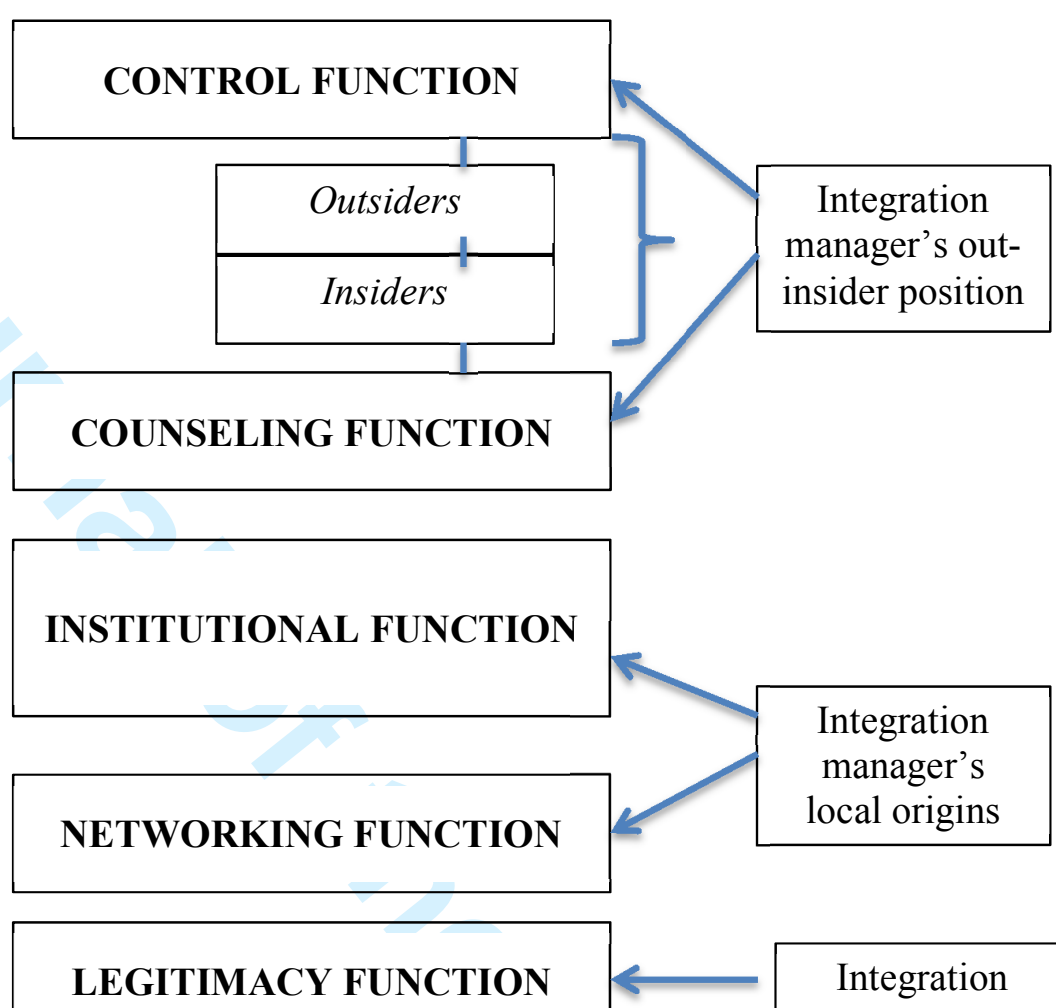
Integration manager's reputation and trustability


Table 1. Summary of the individuals interviewed

\begin{tabular}{|l|l|}
\hline Firm & Interviewees \\
\hline Acquiring firm & CEO (1) Managers (3) \\
\hline Acquired firm & Managers (2) \\
\hline Consultants employed in the acquisition process & Consultants (3) \\
\hline
\end{tabular}


Table 2: Summary of the main features of the case study protocol. Adaptation from Reddy, Xie and Agrawal (2015)

\begin{tabular}{|c|c|}
\hline Area of investigation & Internationalization of firms through cross-border acquisitions \\
\hline Research setting & $\begin{array}{l}\text { This paper proposes the inclusion of the integration manager within } \\
\text { the acquirer's board of directors as the best qualified individual able } \\
\text { to contribute to such crucial CGM through both her/his expertise and } \\
\text { knowledge of the target firm's industry and products }\end{array}$ \\
\hline Research scope & $\begin{array}{l}\text { International business, corporate governance, organization theory, } \\
\text { business planning and evaluation }\end{array}$ \\
\hline Research aim & $\begin{array}{l}\text { We look at the ability of integration managers to serve as "out- } \\
\text { insider" directors able to balance the conflicting demands of two } \\
\text { previously separated entities during their integration process }\end{array}$ \\
\hline $\begin{array}{l}\text { Theoretical and } \\
\text { empirical } \\
\text { contributions }\end{array}$ & $\begin{array}{l}\text { While the role of integration managers is still overlooked by } \\
\text { acquisition scholars (Meglio et al., 2015), this paper highlighted } \\
\text { their importance as additional tools enhancing the effectiveness of } \\
\text { traditional governance devices used to align shareholders and } \\
\text { managers' interests. Through the aid of a case study, we contributed } \\
\text { to such developing literature by testing the success of such } \\
\text { managerial figure. }\end{array}$ \\
\hline $\begin{array}{l}\text { Research } \\
\text { methodology }\end{array}$ & Single case qualitative study \\
\hline Sampling region & European Union \\
\hline Sample cases & $\begin{array}{l}\text { 2PM SpA, an Italian firm operating in the telecommunication } \\
\text { industry } \\
\text { Espanola SA, a Spanish firm operating in the telecommunication } \\
\text { industry }\end{array}$ \\
\hline Temporary frame & $\begin{array}{l}\text { The Preexisting Structure of the Acquiring Firm } \\
\text { The Acquisition of Espanola SA }\end{array}$ \\
\hline $\begin{array}{l}\text { Data collection and } \\
\text { analysis }\end{array}$ & $\begin{array}{l}\text { We collected data at the acquirer's headquarters for approximately } \\
\text { one year, starting in early } 2007 .\end{array}$ \\
\hline Investigator & $\begin{array}{l}\text { The interviews and data coding were developed by two authors. } \\
\text { Other authors validated the analyses in a second moment and } \\
\text { advanced plausible interpretations helpful for improving } \\
\text { international business and corporate governance literature. Editors } \\
\text { and anonymous reviewers effectively contributed to interpret the } \\
\text { results. }\end{array}$ \\
\hline $\begin{array}{l}\text { Literature review } \\
\text { and understanding } \\
\text { of the case method }\end{array}$ & $\begin{array}{l}\text { Literature review focuses on the role of board of directors in the } \\
\text { context of an international acquisition. The implementation of case } \\
\text { study follows Yin (1994). }\end{array}$ \\
\hline
\end{tabular}

